\title{
PENILAIAN KAWASAN KOTA SEMARANG MENGGUNAKAN KPI INFRASTRUKTUR DAN PELAYANAN PERMUKIMAN PERKOTAAN
}

\author{
Subdistrict Assessment of Semarang City Using KPI Infrastructure \\ and Urban Settlement Services
}

Nabila Anjani ${ }^{1}$ dan Fadjar Hari Mardiansjah ${ }^{1}$

Diterima: 18 September 2017

Disetujui: 8 Agustus 2018

\begin{abstract}
Abstrak: Kawasan metropolitan adalah kawasan yang sangat berpengaruh baik untuk perekonomian suatu daerah maupun pusat pergerakan aktivitas dari daerah satu dan terhubung satu sama lain. Infrastruktur kawasan metropolitan harus mendukung guna menunjang kegiatan yang berjalan didalamnya. Guna menilai kinerja sebuah kota maka dibutuhkan indikator yang didapatkan dari turunan KPI dan SDGs. Penelitian ini bertujuan untuk merumuskan dan mengukur Key Performance Indicator (KPI) infrastruktur dan pelayanan permukiman dalam pembangunan perkotaan. Pengukuran nilai kawasan kota ini dilihat dari empat aspek yaitu infrastruktur, pendidikan, ekonomi dan kesehatan. Kota Semarang dibagi menjadi empat kawasan yaitu kawasan pusat kota, kawasan pinggiran selatan, kawasan pinggiran timur dan kawasan pinggiran barat. Penilaian kinerja kota akan menggunakan Key Performance Indicator yang akan distandarisasi sehingga dapat ditotal dengan bobot yang diperhitungkan. Hasil dar KPI total dibandingkan antar kawasan sehingga dapat terlihat kawasan yang tidak mendapat pelayanan dasar permukiman perkotaan secara adil serta hasil KPI dilihat antar waktu untuk melihat perkembangan pelayanan dasar.
\end{abstract}

Kata Kunci: Metropolitan, Infrastruktur, Pelayanan Permukiman, SDGs, Key Performance Indicator

\begin{abstract}
The metropolitan area is an area that is very influential both for the economy of an area as well as the center of activity movement from one area and connected to each other. Infrastructure of metropolitan areas should support the activities that run on it. In order to assess the performance of a city the the required indicators derived from derivatives of KPI and SDGs. This study aims to formulate and measure the Key Performance Indicator (KPI) infrastructure and settlement services in urban development. Measuring the value of this city area is seen from four aspects, namely infrastructure, education, economy and health. The city of Semarang is divided into four areas, namely the downtown area, the southern suburbs, the eastern suburbs and the western suburbs. The city performance appraisal will use the Key Performance Indicator to be standarized so that it can be total by calculated weights. Results of total KPI are compared between regions so that it can be seen areas that do not get basic services of urban settlements fairly and KPI results are seen between times to see the development of basic services.
\end{abstract}

Keywords: Metropolitan, Infrastructure, Settlement Service, SDGs, Key Performance Indicator

\footnotetext{
${ }^{1}$ Departemen Perencanaan Wilayah dan Kota, Fakultas Teknik, Universitas Diponegoro
} 


\section{PENDAHULUAN}

Kawasan metropolitan merupakan sebuah kawasan yang di desain sebagai teritori untuk satu atau lebih pusat kota tergantung fungsi masing-masing kota tersebut yang saling terhubung satu sama lain baik oleh jalan maupun fasilitas transportasi lainnya. Guna mewujudkan kawasan metropolitan yang bisa memenuhi fungsinya dengan baik maka pemenuhan goal yang telah ditetapkan baik dari Millenium Development Goals, Sustainable Development Goals dan Key Performance Indicator infrastruktur menjadi penting untuk mewujudkan kota agar lebih baik dan berkelanjutan. Seluruh goal yang terdapat dalam Key Performance Indicator yang telah ditetapkan oleh Kementerian Pekerjaan Umum dan Perumahan Rakyat merupakan turunan dari goal yang telah ditetapkan MDGs, SDGs maupun peraturan pemerintah.

Infrastruktur yang baik diharapkan dapat dinikamati oleh seluruh warga tanpa terkecuali. Penurunan angka kemiskinan dan pengembangan berkelanjutan adalah dua hal yang tidak dapat dipisahkan dan penurunan angka kemiskinan merupakan bagian dari pengembangan berkelanjutan. Kemiskinan merupakan salah satu masalah institusi dimana budaya miskin terus menerus dibangun karena masalah status quo yang membuat masyarakat kelas bawah terus menerus dibuat bergantung bukannya dibuat berdaya dan dapat berdiri karena kakinya sendiri. Keadilan yang merata juga sulit diterapkan dikarenakan definisi keadilan itu sendiri masih memiliki multi definisi di setiap lapisan masyarakat.

Saat ini dunia menghadapi bahaya akan perubahan iklim yang membawa dampak serius kepada agenda pengembangan dan pemberantasan kemiskinan dari beberapa dimensi seperti, pemberantasan kelaparan, fasilitas kesehatan serta infrastruktur dasar (Qian-Qian, 2015). Oleh karena itu sebuah kota memerlukan sebuah indikator untuk penilaian kinerja kota tersebut dalam pemenuhan infrastruktur dasar yang didalam penelitian ini menggunakan Key Performance Indicator infrastruktur permukiman. KPI infrastruktur permukiman tidak hanya fokus kepada infrastruktur yang sehat dan bersih tetapi juga bagaimana membuat warga yang bermartabat dengan bekerja agar bisa menikmati seluruh infrastruktur dasar tersebut. Sebuah wilayah tidak hanya fokus dalam melayani infrastruktur dasar saja tetapi juga harus bisa membangun lingkungan agar dapat tercipta lingkungan yang mandiri.

Kepercayaan akan keadilan sosial memainkan peran fundamental di kebiasaan politik masyarakat dan pemahaman masyarakat akan politik (Smith, 2010). Multidefinisi dari keadilan membuat pelayanan yang adil juga sulit didapatkan. Warga menengah ke bawah juga sulit untuk mendapatkan fasilitas pelayanan dasar berbayar guna meningkatkan kualitas hidup serta lingkungannya. Dengan tercukupinya seluruh masyarakat dengan fasilitas pelayanan dasar yang sesuai dengan pedoman, diharapkan dapat meningkat pula kualitas lingkungannya. Meskipun hal ini masih merupakan impian semata di Kota Semarang yang masih memiliki kesenjangan antar kawasannya.

Infrastruktur yang baik merupakan hak dari seluruh warga negara tanpa terkecuali. Peningkatan infrastuktur yang baik diharapkan pula dapat mengembangkan kapasitas warga yang dapat meningkat pula kualitas hidup dan lingkungannya. Tetapi pada kenyataannya kinerja infrastruktur dan pelayanan permukiman kota belum dapat diukur untuk mengetahui sejauh mana implikasi perencanaan pembangunan Kota Semarang. Penelitian ini akan merumuskan Key Performance Indicator berbasis kecamatan yang merupakan indikator untuk menyusun kinerja kunci pelayanan infrastruktur dan pelayanan permukiman engan menggunakan data berbasis kecamatan untuk melihat sejauh mana kondisi infrastruktur dan pelayanan permukiman Kota Semarang. 


\section{METODE}

Metode penelitian merupakan cara utama yang digunakan peneliti mencapai tujuan dan menentukan jawaban atas masalah yang diajukan. Metode penelitian juga bisa diartikan sebagai cara ilmiah untuk mendapatkan data dengan tujuan dan kegunaan tertentu. Metode yang digunakan dalam penelitian ini adalah kuantitatif. Menurut Sugiono (2008), metode kuantitatif adalah pendekatan ilmiah yang memandang suatu realitas itu dapat diklasifikasikan, konkrit, teramati dan terukur, hubungan variabelnya bersifat sebab akibat dimana data penelitiannya berupa angka-angka dan analisisnya menggunakan statistik.

Data yang digunakan dalam penelitian ini berupa data sekunder yang didapatkan dari monografi yang telah dipublikasi maupun data dinas terkait yang selanjutnya akan diolah lagi menggunakan aplikasi pemetaan ruang. Dari data tersebut akan dikalkulasi sehingga mengeluarkan nilai KPI dalam bentuk persen untuk melihat sejauh mana gap antar kawasan maupun antar kecamatan yang dapat dilihat per indikator maupun per aspek. Keluaran dari KPI total dibandingkan kembali dengan kepadatan penduduk sehingga didapatkan implikasi perencanaan pembangunan yang akan mengelompokkan kecamatan menjadi beberapa kelompok sehingga dapat diberikan rekomendasi per kelompok tersebut.

\section{Penilaian KPI Tahun 2015}

Penilaian KPI Tahun 2015 mencakup empat aspek yaitu infrastruktur, pendidikan, ekonomi dan kesehatan. Keempat aspek tersebut memiliki indikator untuk mengukur tingkat pelayanan. Data yang digunakan dalam penilaian KPI tahun 2015 ini merupakan kompilasi data dari monografi serta data dari dinas terkait.

Key Performance Indicator (KPI) adalah indikator kunci yang digunakan untuk menilai kinerja sebuah objek. Dalam penelitian ini KPI digunakan sebagai alat untuk menilai kinerja kawasan Kota Semarang. Kelompok indikator yang digunakan dalam KPI ini merupakan turunan dari KPI infrastrutur skala kota yang telah disusun oleh BPIW Kementerian PUPR serta Sustainable Development Goals (SDGs) yang indikatornya disusun skala negara. Dari KPI yang telah disusun BPIW dan indikator SDGs yang telah diseleksi sesuai keterkaitan dan ketersediaan data untuk penyusunan KPI berbasis kecamatan untuk Kawasan Kota Semarang. Perumusan KPI berbasis kecamatan ini dilakukan dengan memadukan indikator yang telah diseleksi dengan data yang tersedia untuk disesuaikan.

Indikator yang dibahas dalam aspek infrastruktur meliputi tingkat pelayanan jalan, tingkat pelayanan air bersih, tingkat pelayanan persampahan, tingkat pelayanan sanitasi, persentase permukiman kumuh, persentase ruang terbuka hijau dan tingkat pelayanan angkutan umum. Indikator yang digunakan dalam aspek infrastruktur mayoritas merupakan turunan dari KPI Infrastruktur Permukiman. Penilaian aspek ini untuk melihat sejauh mana Kota Semarang yang dilihat per kawasan dan per kecamatan dapat melayani warganya dalam hal infrastruktur.

Indikator yang dibahas dalam aspek pendidikan meliputi tingkat pelayanan di keempat jenjang pendidikan yaitu taman kanak-kanak, sekolah dasar, sekolah menengah pertama dan sekolah menengah atas. Setiap tingkat pelayanan mempertimbangkan tiga indikator lainnya yaitu ketersediaan sarana, ketersediaan tenaga pengajar dan partisipasi sekolah. Penilaian aspek ini untuk melihat sebaik apa pelayanan pendidikan di Kota Semarang yang dilihat dari ketersediaan sarana baik fisik maupun tenaga pengajarnya serta partisipasi jumlah usia bersekolah di Kota Semarang.

Indikator yang dibahas dalam aspek ekonomi meliputi ketersediaan sarana yaitu pasar, warung dan minimarket, PDRB per kapita dan tingkat kesejahteraan rendah. 
Penilaian aspek ini untuk melihat ketimpangan ekonomi baik dilihat dari pendapatan, ketersediaan sarana fisik serta keluaran jumlah individu kesejahteraan rendah.

Indikator yang dibahas dalam aspek kesehatan meliputi ketersediaan sarana yaitu puskesmas, klinik dan tempat tidur, ketersediaan tenaga kesehatan serta angka kejadian penyakit endemik. Penilaian ini untuk melihat sebaran fasilitas dan tenaga kesehatan sebagai supply dari aspek kesehatan serta angka penyakit sebagai demand yang terkait dengan keempat aspek yaitu infrastruktur, pendidikan, ekonomi dan kesehatan.

Keempat aspek tersebut lalu disatukan untuk mendapatkan nilai KPI total. Berikut adalah tabel perhitungan KPI total tahun 2015:

Tabel 1. Perhitungan KPI Total Tahun 2015

\begin{tabular}{|c|c|c|c|c|c|}
\hline Kawasan & $\begin{array}{c}\text { KPI Infrastruktur } \\
\text { Total }\end{array}$ & $\begin{array}{c}\text { KPI } \\
\text { Pendidikan } \\
\text { Total } \\
\end{array}$ & $\begin{array}{l}\text { KPI Ekonomi } \\
\text { Total }\end{array}$ & $\begin{array}{c}\text { KPI } \\
\text { Kesehatan } \\
\text { Total } \\
\end{array}$ & KPI Total \\
\hline Semarang Tengah & $71 \%$ & $161 \%$ & $239 \%$ & $52 \%$ & $131 \%$ \\
\hline Semarang Timur & $83 \%$ & $114 \%$ & $214 \%$ & $78 \%$ & $122 \%$ \\
\hline Semarang Selatan & $90 \%$ & $126 \%$ & $234 \%$ & $34 \%$ & $121 \%$ \\
\hline Semarang Utara & $61 \%$ & $97 \%$ & $186 \%$ & $50 \%$ & $98 \%$ \\
\hline Semarang Barat & $51 \%$ & $96 \%$ & $115 \%$ & $67 \%$ & $82 \%$ \\
\hline Gayamsari & $77 \%$ & $88 \%$ & $120 \%$ & $65 \%$ & $88 \%$ \\
\hline Gajahmungkur & $79 \%$ & $101 \%$ & $111 \%$ & $76 \%$ & $92 \%$ \\
\hline Candisari & $54 \%$ & $88 \%$ & $127 \%$ & $54 \%$ & $81 \%$ \\
\hline Kawasan Pusat Kota & $66 \%$ & $105 \%$ & $164 \%$ & $67 \%$ & $100 \%$ \\
\hline Tembalang & $55 \%$ & $75 \%$ & $111 \%$ & $33 \%$ & $68 \%$ \\
\hline Banyumanik & $67 \%$ & $90 \%$ & $114 \%$ & $87 \%$ & $90 \%$ \\
\hline Gunungpati & $59 \%$ & $90 \%$ & $193 \%$ & $16 \%$ & $89 \%$ \\
\hline $\begin{array}{ll}\text { Kawasan } & \text { Pinggiran } \\
\text { Selatan } & \\
\end{array}$ & $60 \%$ & $82 \%$ & $129 \%$ & $51 \%$ & $81 \%$ \\
\hline Genuk & $63 \%$ & $86 \%$ & $188 \%$ & $87 \%$ & $106 \%$ \\
\hline Pedurungan & $47 \%$ & $77 \%$ & $139 \%$ & $70 \%$ & $83 \%$ \\
\hline Kawasan Pinggiran Timur & $50 \%$ & $80 \%$ & $156 \%$ & $78 \%$ & $91 \%$ \\
\hline Mijen & $58 \%$ & $97 \%$ & $122 \%$ & $40 \%$ & $79 \%$ \\
\hline Ngaliyan & $62 \%$ & $73 \%$ & $115 \%$ & $54 \%$ & $76 \%$ \\
\hline Tugu & $71 \%$ & $96 \%$ & $126 \%$ & $58 \%$ & $88 \%$ \\
\hline Kawasan Pinggiran Barat & $62 \%$ & $83 \%$ & $119 \%$ & $52 \%$ & $79 \%$ \\
\hline Kota Semarang & $60 \%$ & $91 \%$ & $149 \%$ & $77 \%$ & $94 \%$ \\
\hline
\end{tabular}

Sumber: Hasil Analisis, 2017

Perhitungan KPI untuk infrastruktur dapat dilihat bahwa kecamatan yang ada di kawasan pusat kota cenderung sudah melampaui dari nilai Kota Semarang yang berarti telah cenderung berstatus baik untuk pelayanan infrastruktur di kecamatan tersebut. Meskipun begitu, masih tetap banyak kecamatan yang masih berada di bawah rata-rata Kota Semarang yaitu 54\%.

Perhitungan KPI untuk pendidikan dapat dilihat bahwa pelayanan pendidikan di Kota Semarang sudah cukup baik karena nilai KPI total pendidikan telah banyak yang melampaui angka 100\%. Meskipun masih ada beberapa kecamatan yang berada dibawah nilai $100 \%$ tetapi nilai untuk kecamatan tersebut masih mendekati $100 \%$.

Perhitungan KPI untuk ekonomi dapat dilihat bahwa nilai totalnya telah diatas $100 \%$ seluruhnya. Hal ini disebabkan oleh tingkat pelayanan sarana ekonomi yang dominan berada diatas 100\% terlebih untuk minimarket yang memang menjadi salah satu fenomena di Kota Semarang yang jarak antar minimarket sudah tidak begitu diperhatikan.

Perhitungan KPI untuk kesehatan dapat dilihat bahwa masih banyak kecamatan yang berada dibawah nilai Kota Semarang yaitu 77\%. Dominan yang berada diatas rata-rata 
adalah kawasan pusat kota dan kawasan pinggiran timur meskipun masih ada kecamatan dalam kawasan pusat kota yang berada dibawah rata-rata. Seluruh kawasan masih berada dibawah rata-rata nilai Kota Semarang kecuali kawasan pinggiran timur dengan nilai 78\% yang meskipun sangat tipis berbeda dengan nilai Kota Semarang.

Perhitungan KPI total dapat dilihat bahwa nilai untuk Kota Semarang adalah $92 \%$. Beberapa kecamatan yang berada dibawah rata-rata nilai tersebut masih berada dalam batas wajar dan tidak terlalu jauh selisih angkanya meskipun ada satu kecamatan yang memiliki selisih tertinggi yaitu Kecamatan Tembalang. Hal ini diakibatkan karena nilai infrastruktur dan pendidikannya lebih kecil dibanding kecamatan lain.

\section{Penilaian KPI Antar Waktu}

Pembuatan KPI antar waktu dibutuhkan data yang didapatkan baik dari monografi maupun data yang dimiliki dinas terkait. Kompilasi dari data tersebut dijadikan acuan untuk penentuan pembuatan indikator KPI yang akan dibuat. Melihat keterbatasan data sangat disayangkan bahwa penilaian KPI antar waktu hanya dapat membandingkan dua aspek saja yaitu infrastruktur dan pendidikan.

Aspek infrastruktur hanya akan dibahas dua indikator yang itu tingkat pelayanan air bersih dan tingkat pelayanan TPS. Sedangkan untuk aspek pendidikan karena data yang dibutuhkan selalu tersedia di setiap tahun maka seluruh indikator dapat digunakan.

Indikator tingkat pelayanan air bersih menggunakan data KK pengguna PDAM pada tahun 2000, 2005, 2010 dan 2015. Dalam data tersebut tingkat pelayanan air bersih mengalami penurunan setiap tahunnya. Hal ini dikarenakan jumlah supply yang tersedia tidak mampu menampung demand yang ada sehingga setiap tahun angka pelayanan semakin menurun.

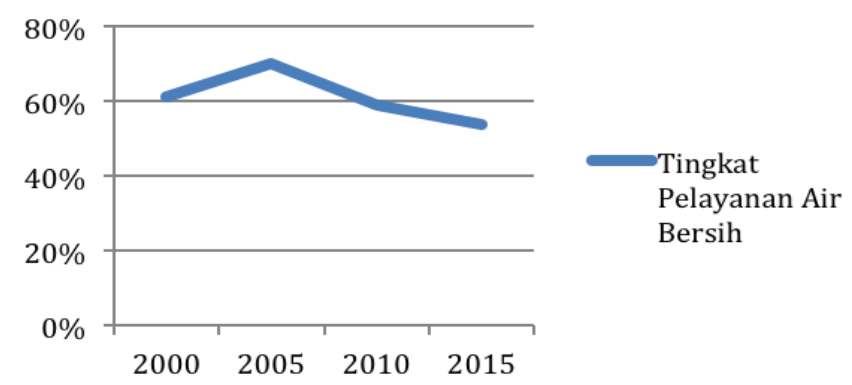

(Sumber: Hasil Analisis, 2017)

Gambar 1. Grafik Perkembangan Tingkat Pelayanan Air Bersih Kota Semarang

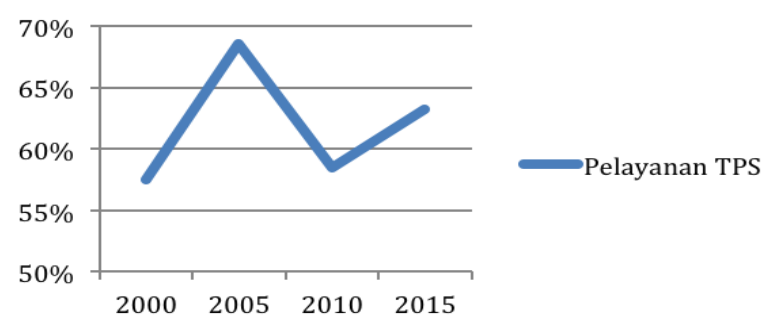

(Sumber: Hasil Analisis, 2017)

Gambar 2. Grafik Perkembangan Tingkat Pelayanan TPS Kota Semarang 
Dilihat dari grafik pada Gambar 1, tingkat pelayanan air bersih di Kota Semarang menunjukkan adanya penurunan setiap lima tahunnya sehingga pada tahun 2015 berada pada angka 54\% jumlah KK yang menggunakan PDAM.

Indikator tingkat pelayanan tempat pembuangan sampah menggunakan data jumlah container pada tahun 2000, 2005, 2010 dan 2015. Dalam data tersebut terlihat bahwa pelayanan TPS mengalami fluktuasi setiap tahunnya. Fluktuasi ini bisa diakibatkan jumlah container yang dibutuhkan semakin banyak mengingat jumlah penduduk setiap tahunnya bertambah dan kebutuhan akan container bertambah pula.

Dilihat dari grafik pada Gambar 2, pelayanan TPS Kota Semarang pada setiap 5 tahunnya mengalami fluktuasi. Angka tertinggi terdapat pada tahun 2005 yaitu $69 \%$ lalu turun pada tahun 2010 menjadi 58\% dan kembali naik menjadi 53\% pada tahun 2015. Angka yang masih menyentuh angka dekat dengan 50\% menandakan bahwa kebutuhan container masih belum terpenuhi seluruhnya.

Indikator tingkat pelayanan taman kanak-kanak menggunakan data dari perhitungan indikator sebelumnya yaitu ketersediaan sarana, ketersediaan tenaga pengajar dan partisipasi sekolah pada tahun 2000, 2005, 2010 dan 2015. Dalam data tersebut terlihat bahwa tingkat pelayanan taman kanak-kanak mengalami kenaikan. Kenaikan tingkat pelayanan terjadi paling tinggi dari tahun 2005 ke tahun 2010, kenaikan hingga mencapai $6 \%$ untuk Kota Semarang. Tingkat pelayanan taman kanak-kanak jika dilihat per kecamatan sudah cukup baik karena mayoritas kecamatan telah melampaui angka $70 \%$ bahkan di kawasan pusat kota telah ada yang mencapai 100\% di tahun 2015 .

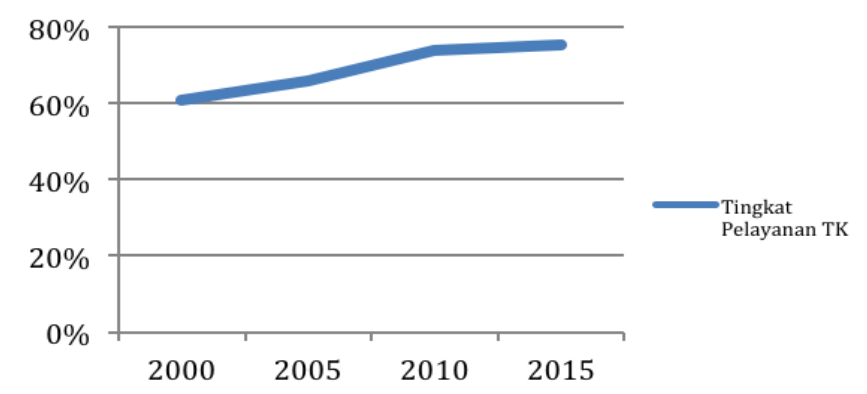

(Sumber: Hasil Analisis, 2017)

\section{Gambar 3. Grafik Perkembangan Tingkat Pelayanan TK Kota Semarang}

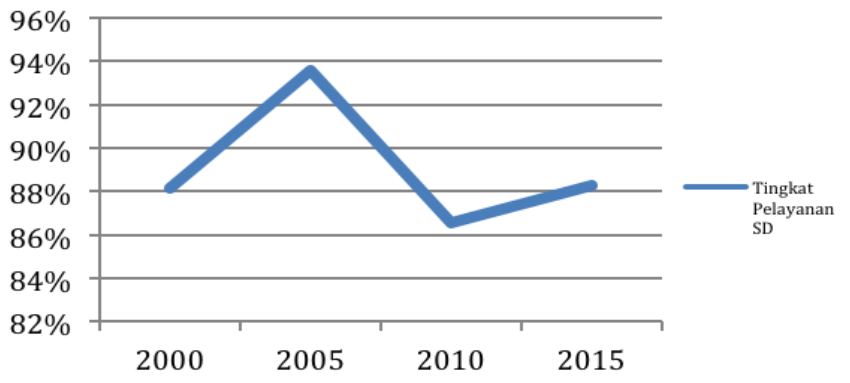

(Sumber: Hasil Analisis, 2017)

Gambar 4. Grafik Perkembangan Tingkat Pelayanan SD Kota Semarang 
Dilihat dari grafik pada Gambar 3, pelayanan taman kanak-kanak di Kota Semarang terus mengalami kenaikan dari tahun 2000 hingga tahun 2015 yang mencapai nilai $75 \%$. Indikator tingkat pelayanan sekolah dasar menggunakan data dari perhitungan indikator sebelumnya yaitu ketersediaan sarana, ketersediaan tenaga pengajar dan partisipasi sekolah pada tahun 2000, 2005, 2010 dan 2015. Dalam data tersebut dapat dilihat bahwa tingkat pelayanan sekolah dasar mengalami fluktuasi. Penurunan terjadi paling tinggi dari tahun 2005 ke tahun 2010, penurunan hingga mencapai 7\% untuk Kota Semarang. Dilihat dari grafik diatas, pelayanan sekolah dasar di Kota Semarang mengalami fluktuasi dari tahun ke tahun. Pada tahun 2005 dari tahun 2000 mengalami kenaikan hingga menyentuh angka 94\%. Namun mengalami penurunan kembali pada tahun 2010 menjadi $87 \%$ dan mengalami sedikit kenaikan pada tahun 2015 menjadi 88\%. Indikator tingkat pelayanan sekolah menengah pertama menggunakan data dari perhitungan indikator sebelumnya yaitu ketersediaan sarana, ketersediaan tenaga pengajar dan partisipasi sekolah pada tahun 2000, 2005, 2010 dan 2015. Dalam data tersebut dapat dilihat bahwa tingkat pelayanan sekolah menengah pertama mengalami fluktuasi karena data pendukungnya mengalami fluktuasi pula. Kenaikan paling tinggi terjadi dari tahun 2010 ke tahun 2015 hingga mencapai 5\% untuk Kota Semarang.

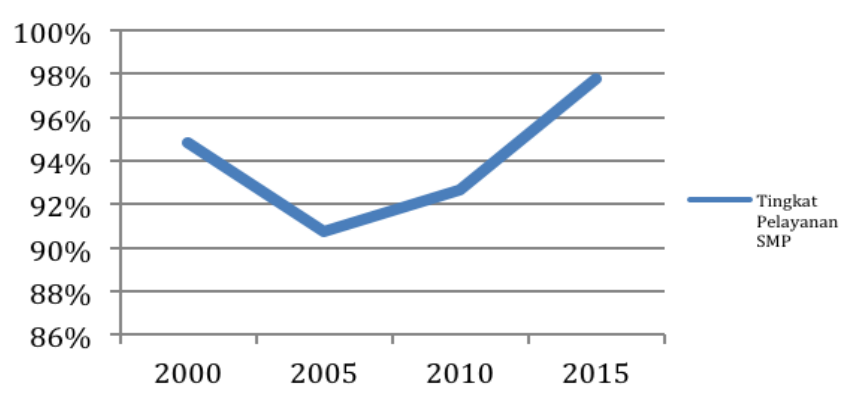

(Sumber: Hasil Analisis, 2017)

Gambar 5. Grafik Perkembangan Tingkat Pelayanan SMP Kota Semarang

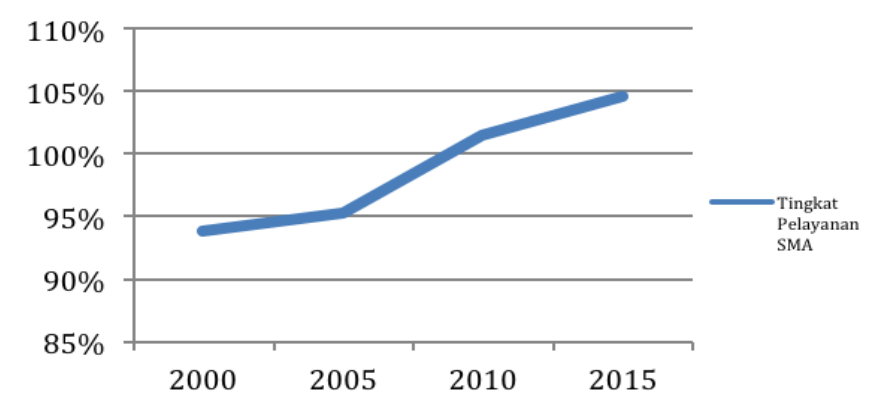

(Sumber: Hasil Analisis, 2017)

\section{Gambar 6. Grafik Perkembangan Tingkat Pelayanan SMA Kota Semarang}

Dilihat dari grafik pada Gambar 5, pelayanan sekolah menengah pertama di Kota Semarang sempat mengalami penurunan pada tahun 2005 tetapi kembali naik pada tahun 2010 dan 2015 hingga mencapai nilai 98\%. Indikator tingkat pelayanan sekolah menengah 
atas menggunakan data dari perhitungan indikator sebelumnya yaitu ketersediaan sarana, ketersediaan tenaga pengajar dan partisipasi sekolah pada tahun 2000, 2005, 2010 dan 2015. Dalam data tersebut dapat dilihat bahwa pelayanan sekolah menengah atas terus mengalami kenaikan. Kenaikan terjadi paling tinggi dari tahun 2005 ke tahun 2010 hingga mencapai $7 \%$.

Dilihat dari grafik pada Gambar 6, perkembangan tingkat pelayanan sekolah menengah atas di Kota Semarang mengalami kenaikan yang signifikan. Dari tahun 2000 dengan angka 94\% dan nai di tahun 2015 menjadi 105\%.

\section{Implikasi Perencanaan Pembangunan}

Implikasi perencanaan pembangunan membandingkan kepadatan penduduk dengan nilai KPI yang telah didapatkan diatas. Selanjutnya akan dilihat implikasi perencanaan pembangunan untuk per kelompok dilihat dari hasil perbandingan tersebut. Berikut grafik implikasi perencanaan pembangunan di Gambar 7

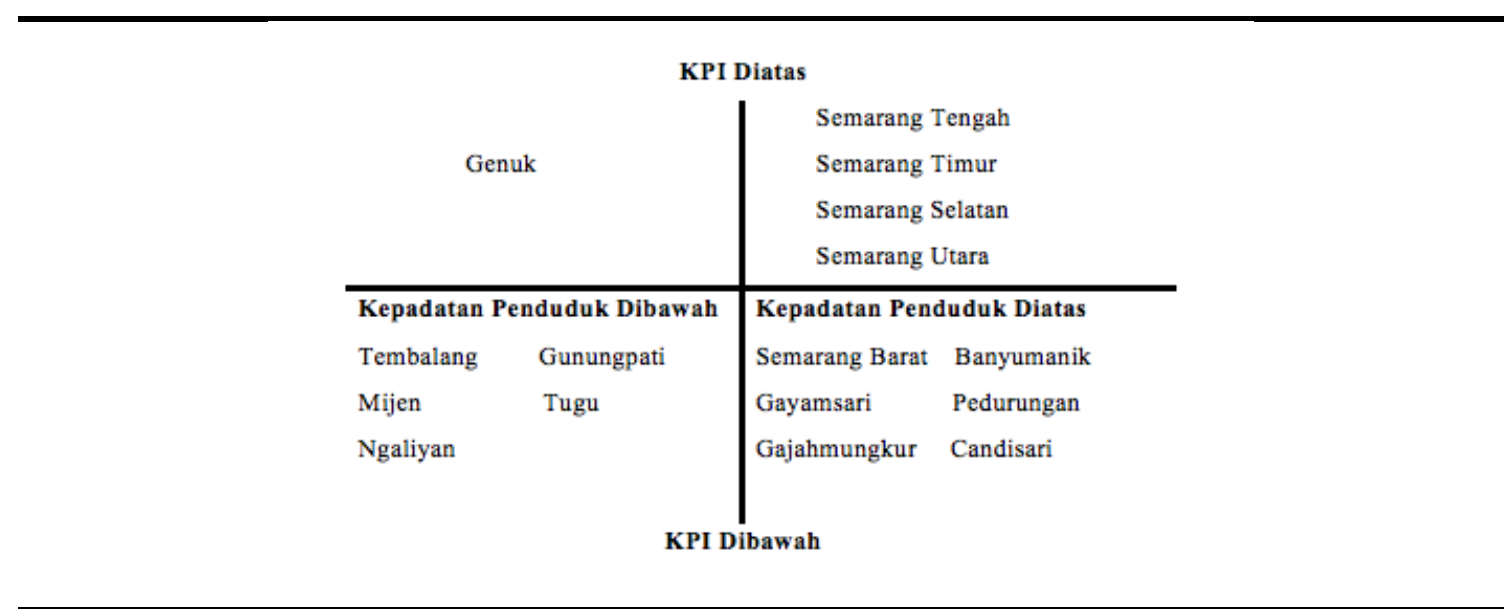

Sumber: Hasil Analisis, 2017

\section{Gambar 7. Grafik Implikasi Perencanaan Pembangunan}

a. KPI Diatas dan Kepadatan Penduduk Diatas

Kecamatan yang termasuk dalam kelompok ini merupakan kecamatan yang berada di pusat Kota Semarang yaitu Semarang Tengah, Semarang Timur, Semarang Selatan dan Semarang Utara. Keempat kecamatn tersebut memiliki kepadatan penduduk yang jauh melampaui kepadatan penduduk Kota Semarang, meskipun begitu angka KPI untuk pelayanan di kecamatan juga jauh melampaui angka KPI untuk Kota Semarang. Hal ini mengartikan bahwa keempat kecamatan tersebut telah mampu melayani penduduknya dengan infrastruktur dasar dan pelayanan permukiman sehingga tidak diperlukan untuk peningkatan pelayanan ataupun penekanan jumlah penduduk.

b. KPI Diatas dan Kepadatan Penduduk Dibawah

Kecamatan yang termasuk dalam kelompok ini hanya terdapat satu kecamatan yaitu Genuk. Kecamatan ini memiliki KPI diatas rata-rata Kota Semarang dengan nilai 104\% dimana nilai yang unggul disumbang dari infrastruktur, ekonomi dan kesehatan. Sedangkan hal ini berkebalikan dengan kepadatan penduduknya yang masih dibawah rata-rata Kota Semarang yaitu 3.561 orang tiap $\mathrm{km}^{2}$ dimana kepadatan penduduk Kota Semarang adalah 4.269 orang tiap $\mathrm{km}^{2}$ tetapi angka KPI untuk Genuk jauh melampaui rata-rata Kota Semarang. Hal ini mengartikan bahwa Genuk telah mampu melayani seluruh warganya 
bahkan melampaui dari kebutuhan warganya. Oleh karena itu, Genuk dapat meningkatkan jumlah penduduknya baik dengan perpindahan dari kecamatan lain maupun dari kelahiran. c. KPI Dibawah dan Kepadatan Penduduk Diatas

Kecamatan yang berada di kelompok ini adalah Semarang Barat, Gayamsari, Gajahmungkur, Candisari, Banyumanik dan Pedurungan. Keenam kecamatan tersebut memiliki kepadatan penduduk yang melampaui kepadatan penduduk Kota Semarang tetapi memiliki angka KPI yang berada dibawah angka KPI Kota Semarang. Hal ini mengartikan bahwa keenam kecamatan tersebut butuh peningkatan infrastruktur dan pelayanan permukiman serta butuh juga ditekan jumlah penduduknya.

d. KPI Dibawah dan Kepadatan Penduduk Dibawah

Kecamatan yang berada di kelompok ini adalah Tembalang, Gunungpati, Mijen, Ngaliyan dan Tugu. Kelima kecamatan tersebut memiliki kepadatan penduduk yang berada dibawah kepadatan penduduk Kota Semarang serta angka KPI yang masih dibawah angka KPI Kota Semarang. Hal ini mengartikan bahwa kelima kecamatan tersebut butuh peningkatan infrastruktur dan pelayanan permukimannya guna melayani kebutuhan dasar warga tanpa terkecuali.

\section{HASIL}

\section{Hasil Pengukuran Total}

Kecamatan di kawasan pusat kota mayoritas memiliki nilai yang baik. Diantara keempat aspek yang dibahas, kawasan pusat kota bisa dibilang unggul di seluruh indikator jika dibandingkan dengan kawasan lainnya. Kecamatan dengan nilai paling tinggi di kawasan ini adalah Kecamatan Semarang Tengah dengan nilai pendidikan dan ekonomi paling tinggi diantara kecamatan lainnya. Kecamatan dengan nilai paling rendah yaitu Kecamatan Candisari yang juga berada dibawah nilai Kota Semarang, nilai yang paling rendah dibanding seluruh kecamatan adalah pendidikan meskipun nilai ketiga aspek lainnya tidak paling rendah tetapi memiliki gap yang lebih dekat dengan nilai terendah.

Kecamatan di kawasan pinggiran selatan memiliki nilai KPI total yang berada di bawah nilai Kota Semarang. Kecamatan dengan perolehan nilai tertinggi di kawasan ini adalah Kecamatan Banyumanik dengan aspek terunggulnya adalah infratsruktur, pendidikan dan kesehatan. Kecamatan dengan nilai terendah adalah Kecamatan Tembalang yang juga menjadi kecamatan dengan perolehan nilai paling rendah untuk Kota Semarang, nilai Kecamatan Tembalang terendah untuk aspek pendidikan, ekonomi dan kesehatan.

Kecamatan di kawasan pinggiran timur memiliki nilai KPI total yang berada di bawah Kota Semarang meskipun gapnya tidak terlalu jauh. Kecamatan Genuk memiliki nilai KPI total yang cukup tinggi jika dibandingkan dengan kecamatan di Kota Semarang lainnya. Kecamatan ini memiliki nilai lebih unggul dibandingkan Kecamatan Pedurungan di keempat aspek.

Kecamatan di kawasan pinggiran barat memiliki nilai KPI total terendah bila dibandingkan dengan kawasan lainnya. Kecamatan di kawasan ini dengan perolehan nilai tertinggi adalah Kecamatan Tugu yang unggul di infrastruktur, ekonomi dan kesehatan. Sedangkan Kecamatan Mijen dan Kecamatan Ngaliyan memiliki nilai hanya selisih satu.

Indikator tingkat pelayanan angkutan umum menyumbang nilai terbesar untuk aspek infrastruktur mengingat nyaris seluruh kecamatan telah terlayani dengan baik oleh keberadaan angkutan umum.

Indikator tingkat ketersediaan tenaga pengajar menyumbang nilai terbesar untuk aspek pendidikan karena mayoritas telah mencapai nilai $100 \%$. Tenaga pengajar yang mayoritas telah memenuhi standar dari peraturan pemerintah menyumbang tambahan nilai yang cukup banyak untuk beberapa kecamatan. 
Indikator tingkat ketersediaan sarana ekonomi menyumbang nilai terbesar untuk aspek ekonomi karena mayoritas kecamatan telah memenuhi kebutuhan akan sarana ekonomi. Sarana ekonomi yang menyumbang nilai tertinggi adalah jumlah warung kelontong yang membuat beberapa kecamatan unggul di aspek ekonomi karena banyaknya jumlah warung kelontong yang kecamatan tersebut miliki.

Indikator tingkat pelayanan klinik menyumbang nilai terbesar untuk aspek kesehatan karena telah berhasilnya mayoritas kecamatan untuk memenuhi kebutuhan klinik.

Kawasan yang memiliki nilai paling tinggi untuk KPI total adalah kawasan pusat kota lalu disusul oleh kawasan pinggiran timur, kawasan pinggiran selatan dan kawasan pinggiran barat.

Dilihat dari hasil KPI total, ada beberapa indikator yang butuh perhatian lebih untuk peningkatan kinerjanya. Dari aspek infrastruktur butuh diperhatikan tingkat pelayanan jalan dan tingkat pelayanan air bersih yang masih banyak kecamatan yang nilainya dibawah 50\% serta persentase RTH yang masih memiliki persentase yang sangat kecil. Dari aspek pendidikan belum ada yang harus dikhawatirkan karena dari ketiga indikator yang dihitung telah dalam keadaan baik seluruhnya. Dari aspek ekonomi perlu diperhatikan tingkat kesejahteraan rendah yang masih ada beberapa kecamatan berada diatas $10 \%$. Dari aspek kesehatan butuh diperhatikan tingkat pelayanan tempat tidur dan tenaga kesehatan yang persentasenya masih sangat kecil.

\section{Cara Pengukuran}

Indikator yang dapat dihitung untuk antar waktu hanya dapat dilihat dari dua aspek, yaitu infrastruktur dan pendidikan. Hal ini disebabkan oleh keterbatasan data monografi yang spesifik guna penilaian KPI infrastruktur dan pelayanan permukiman perkotaan.

Indikator yang dapat dibuat secara antar waktu untuk aspek infrastruktur adalah tingkat pelayanan air bersih dan tingkat pelayanan TPS. Meskipun dapat dihitung pula setiap tahun untuk volume sampah perhari, tetapi tidak dimasukkan menjadi indikator karena kurangnya varian data untuk kawasan dan kecamatan.

Indikator untuk aspek pendidikan adalah tingkat pelayanan mulai dari taman kanakkanak, sekolah dasar, sekolah menengah pertama dan sekolah menengah atas. Perbandingan antar waktu dapat dilakukan di seluruh indikator pendidikan karena data yang dibutuhkan keluar secara kontinyu di data monografi.

Aspek ekonomi dan kesehatan tidak memiliki indikator yang dapat dihitung antar waktu dikarenakan keterbatasan data yang ada. Untuk ekonomi, terbatas karena tidak adanya daya jumlah sarana maupun tenaga kerja per kecamatan. Sedangkan untuk kesehatan, nyaris seluruh data didapatkan dari dinas kesehatan dan dinas tersebut tidak memiliki data yang kontinyu untuk tahun yang dibutuhkan.

\section{KESIMPULAN}

Kawasan pusat kota merupakan sebuah kawasan yang paling unggul dinilai dari empat aspek penilaian dan peroleh nilai tertinggi dari indikator uga mayoritas berada di kawasan pusat kota. Kawasan pusat kota pula hanya satu-satunya kawasan yang perolehan nilai KPI total melampaui dari nilai Kota Semarang. Seiring dengan baiknya pelayanan di kawasan pusat kota juga sejalan dengan pertumbuhan jumlah penduduknya. Pelayanan yang ada di pusat kota dirasa telah cukup untuk memenuhi kebutuhan penghuninya. Sedangkan kawasan pinggiran lainnya memiliki perolehan nilai KPI total yang berada dibawah nilai KPI Kota Semarang. Kawasan yang memiliki gap terendah adalah kawasan pinggiran timur dimana hal ini terjadi karena Kecamatan Genuk memiliki nilai KPI yang melampaui nilai KPI Kota Semarang dikarenakan tingginya nilai ekonomi karena ketersediaan sarana perekonomian yang cukup banyak di kecamatan tersebut. Sedangkan dua kawasan lainnya, kawasan pinggiran selatan dan kawasan pinggiran barat, memiliki 
gap nilai KPi yang cukup tinggi dari KPI total Kota Semarang. Diantara ketiga kawasan pinggiran tersebut, kawasan pinggiran timur memiliki nilai lebih tinggi dibandingkan kedua kawasan lainnya, hal ini dikarenakan keunggulan sarana perekonomian yang ada di Kecamatan Genuk yang berada di atas rata-rata Kota Semarang. Sedangkan untuk kedua kawasan lainnya memliki nilai gap yang tidak begitu tinggi antara keduanya tetapi memiliki gap yang cukup tinggi bila dibandingkan dengan kawasan pusat kota dan kawasan pinggiran timur.

Perhitungan KPI antar waktu yang tidak bisa dilakukan pada semua indikator disebabkan oleh kurangnya bebrapa data di tahun-tahun sebelumnya sehingga hanya enam indikator saja yang termasuk dalam aspek infrastruktur dan pendidikan saja. Dalam aspek infrastruktur, indikator yang dibahas antar waktu adalah tingkat pelayanan air bersih dan tingkat pelayanan TPS. Sedangkan dalam aspek pendidikan, seluruh indikator dibahas antar waktu. Dari hasil perhitungan, perkembangan pelayanan dari enam indikator tersebut bisa dinilai fluktuatif. Beberapa indikator memiliki kecenderungan menurun karena kurangnya supply akan layanan tersebut sedangkan demand terus bertambah. Sedangkan untuk tingkat pelayanan pendidikan cenderung memiliki perkembangan yang naik meskipun ada juga yang mengalami penurunan, tetapi mengalami kenaikan kembali pada tahun 2015.

Peluang perhitungan KPI ini sangat bisa dilakukan dengan harapan data yang digunakan pada perhitungan tahun 2015 dapat dikeluarkan pula pad atahun setelahnya sehingga perhitungan KPI ini akan dapat terus dilakukan guna menilai kawasan dan kecaatan mana yang butuh perhatian lebih dilihat dari pelayanan dasarnya. Capaian KPI total pula bisa menghasilkan klasifikasi kecamatan yang dibandingkan dengan kepadatan penduduk sehingga dapat ditentukan kecamatan mana yang butuh penambahan sarana atau penekanan jumlah penduduk dan kecamatan mana yang masih mampu menampung jumlah penduduk yang lebih dari keadaan sekarang ini.

\section{Daftar Pustaka}

Anonim. 2016. "Pengertian SDGs (Sustainable Development Goals)". Dalam http://www.ilmu-ekonomiid.com. Diunduh pada 4 November 2016.

Bastie, Jean., Dezert, Bernard. 1991. La Ville. French: Masson.

Camagni, Roberto. Capello, Roberta. Nijkamp, Peter. (1998). “Towards Sustainable City Policy: An EconomyEnvironment Technology Nexus”. Ecological Economics. 24, 103-118.

D' Alessandro, Erminia. (2016). “Creative and Inclusive Centrality for The Metropolitan City”. Procedia- Social and Behavioral Sciences. 223, 321-326.

De Chiara, Joseph. 1975. Manual of Housing/Planning and Design Criteria. Englewood Cliffs, N. J.: PrenticeHall.

Direktorat Jenderal Penataan Ruang, 2006. Metropolitan di Indonesia : Kenyataan dan Tantangan dalam Penataan Ruang. Jakarta: PT. Bina Pratama Asih.

Gilbert, Alan., Gugler, Josef. 1996. Urbanisasi dan Kemiskinan. Yogyakarta: PT. Tiara Wacana Yogya.

Leadership Council of the Sustainable Development Solutions Network. 2015. Indicators and a Monitoring Framework for the SDGs.

Masrun, Riznur. 2007. “Arahan Pemanfaatan Ruang Bagi Pelayanan Minimarket di Kota Tangerang”. Tesis. Pascasarjana Universitas Diponegoro.

Nazir, Muhammad. 1988. Metode Penelitian. Jakarta: Ghalia Indonesia.

Neely, Bernard. (2004). "Intellectual Capital - Defining Key Performance Indicators for Organizational Knowledge Assets”. Business Process Management Journal. 10, 551-569.

Pakzad, Pariza. Osmond, Paul. (2016). "Developing a Sustainability Indicator Set For Measuring Green Infrastructure Performance”. Procedia-Social and Behavioral Sciences. 216, 68-79.

Peraturan Menteri Pekerjaan Umum No. 1 Tahun 2014 tentang Standar Pelayanan Minimal Bidang Pekerjaan Umum dan Penataan Ruang. 
Peraturan Menteri Pekerjaan Umum No. 49 Tahun 2005 tentang Kebijakan dan Strategi Nasional Pengembangan Perkotaan.

Peraturan Pemerintah No. 74 Tahun 2008 tentang Guru.

Qian-Qian, Liu. Man, Yu. Xiao-Lin, Wang. (2015). "Poverty Reduction Within The Framework of SDGs and Post-2015 Development Agenda”. Advances in Climate Change Research. 6, 67-73.

Rasul, Golam. (2016). "Managing The Food, Water and Energy Nexus For Achieving The Sustainable Development Goals in South Asia”. Environmental Development. 18, 14-25.

Reh, F. John, 2016. "The Basic of Key Performance Indicators (KPI)". Dalam http://www.thebalance.com. Diunduh pada 3 November 2016.

Sugiyono. 2008. Metode Penelitian Kuantitatif, Kualitatif dan R\&D. Bandung: CV. Alfabeta.

Undang-Undang No. 26 Tahun 2007 tentang Penataan Ruang.

Vioya, Arrauda. (20)10). "Tahapan Perkembangan Kawasan Metropolitan Jakarta". Jurnal Perencanaan Wilayah dan Kota. 21(3), 215-226. 